\title{
AN ELDERLY PATIENT WITH BILATERAL INTRACRANIAL CALCIFICATION AND SEIZURE
}

\author{
Marina Anggun Sari, ${ }^{1}$ Meiti Frida ${ }^{2}$, Basjiruddin Ahmad ${ }^{3}$
}

\begin{abstract}
Abstrak
Gangguan neurologis terkait usia seperti gangguan serebrovaskular dan neurodegeneratif merupakan faktor etiologi yang paling umum untuk kejang pada orang tua. Sindrom Fahr merupakan gangguan neurodegeneratif yang jarang terjadi, ditandai dengan deposit kalsium simetris pada kedua hemisfer otak, kebanyakan kasus muncul dengan gejala ekstrapiramidal. Seorang pasien wanita usia 64 tahun dirawat dengan kejang umum tonik klonik 12 jam sebelum masuk rumah sakit. Pasien memiliki riwayat kejang 1 bulan sebelumnya, tetapi tidak mengkonsumsi obatobatan. Karena kekakuan pada semua ekstremitas, gerakan yang menjadi lambat, dan perubahan perilaku, pasien lebih sering berbaring di tempat tidur dengan ketergantungan penuh pada aktivitas sehari-hari sejak 1 tahun yang lalu. Pasien memiliki riwayat operasi gondok 30 tahun yang lalu. Pada Brain CT Scan didapatkan kalsifikasi intrakranial bilateral di ganglia basal, periventrikel, subkortikal, serebelum tanpa perifokal edema, dengan kadar kalsium darah yang rendah $(3,6 \mathrm{mg} / \mathrm{dl})$ dan kadar PTH yang sangat rendah $(1,55 \mathrm{pg} / \mathrm{ml})$ yang menunjukkan sindrom Fahr. Pasien mendapatkan terapi antikonvulsan, suplemen kalsium dan calcitriol. Sindrom Fahr harus dipertimbangkan pada pasien dengan manifestasi kejang yang berhubungan dengan kalsifikasi intrakranial, meskipun kasus ini jarang terjadi.
\end{abstract}

Kata Kunci: kalsifikasi intrakranial bilateral, kejang, hipoparatiroid, sindrom Fahr

\begin{abstract}
Age-related neurological disorders such as cerebrovascular and neurodegenerative disorders are the most common etiological factors for seizure in the elderly. Fahr's syndrome is a rare neurodegenerative disorder, characterized by bihemispher symmetrical calcium deposits of the brain, most cases present with extrapyramidal symptoms. Reported an unusual case of Fahr's syndrome in a 64-year-old female patient who presented generalized tonic clonic seizure 12 hours before admission. The patient has been reported for one episode of this seizure a month before, but not taking any medication. Due to stiffness on all extremities, slowness of motion, and change of behaviour, patient mostly lying on a bed with fully dependent in daily activities since last year. The patient had history of goiter and neck surgery 30 years ago. Head CT scan revealed bilateral intracranial calcification in the basal ganglia, periventricular, subcortical white matter and cerebellum. Serum calcium level was low (3.6 mg/dl) and PTH levels was extremely low $(1.55 \mathrm{pg} / \mathrm{ml})$ which suggest a Fahr's syndrome. Patient was given anticonvulsant, calcium and calcitriol supplementation. Although rarely seen, Fahr's syndrome has to be considered in patient with convulsive seizure associated with intracranial calcifications as reported in this case.
\end{abstract}

Key words: bilateral intracranial calcification, Fahr's syndrome, hypoparathyroidism, seizure

Affiliasi penulis: 1. Program Pendidikan Dokter Spesialis Neurologi FK Unand, 2. Bagian Neurologi FK Unand/ RSUP Dr. M. Djamil, Padang, 3. Bagian Neurologi FK Unand /RSUP Dr.M.Djamil Padang
Korespondensi: Marina Anggun Email: marina.anggun@gmail.com Telp/HP :082379633903 


\section{PENDAHULUAN}

Gangguan neurologis terkait usia seperti gangguan serebrovaskular dan neurodegeneratif adalah faktor etiologi yang paling umum untuk epilepsi pada orang tua. ${ }^{1}$ Sindrom Fahr adalah salah satu gangguan degenratif yang jarang ditemui, melibatkan manifestasi kejang, gejala ekstrapiramidal dan gangguan neuropsikiatrik sebagai akibat dari kalsifikasi bilateral simetris dari globus pallidus, putamen, nukleus dentate dari serebelum (striatopallido-dentate calcinosis) dan substansia alba. Kondisi ini disebut sebagai kalsifikasi basalis ganglia idiopatik ketika tidak ada penyebab sekunder yang jelas untuk kalsifikasi tersebut. Sindrom Fahr sebagian besar terkait dengan gangguan metabolisme kalsium dan fosfat, terutama untuk hipoparatiroidisme (HPT), meskipun dapat dikaitkan dengan etiologi lain yang berbeda, termasuk penyakit infeksi, metabolik, dan genetik. $^{2}$ Onset penyakit yang muncul biasanya pada pasien yang usia lanjut, dengan manifestasi yang menjadi lebih sering dan tingkat keparahan yang semakin meningkat. ${ }^{3}$

\section{KASUS}

Seorang pasien wanita berusia enam puluh empat tahun dirawat di bagian saraf RSUP Dr. M. DJamil dengan kejang tonik klonik berulang 12 jam sebelum masuk rumah sakit. Kejang berulang dengan pola yang sama, dan pasien mendapatkan $10 \mathrm{mg}$ diazepam secara intravena untuk menghentikan kejang.

Pasien diketahui memiliki episode kejang dengan pola yang sama satu bulan sebelumnya, tetapi tidak mengkonsumsi obat apa pun. Karena kekakuan pada semua ekstremitas, kelambatan gerak, dan perubahan perilaku, pasien lebih banyak terbaring di tempat tidur dengan ketergantungan pada aktivitas sehari-hari sejak 1 tahun yang lalu. Pasien diketahui menjalani operasi leher 30 tahun yang lalu, tetapi tidak kontrol atau mengonsumsi obat rutin.

Pemeriksaan fisik menunjukkan kondisi umum yang buruk, pasien tampak mengantuk, dengan tekanan darah 120/70 mmHg, nadi $80 \mathrm{x} /$ menit. Ditemukan kekakuan pada leher dan keempat ekstremitas, dengan peningkatan reflek fisiologis dan reflek patologis bilateral serta tanda Chvostek dan Trousseau yang positif.

Laboratorium saat pasien masuk menunjukkan hipokalsemia (kalsium total 3,6 mg/dl (dengan kadar normal $8,1-10,4 \mathrm{mg} / \mathrm{dl}$ ), dan kalsium ionik 0,14 $\mathrm{mmol} / \mathrm{L}$ (kadar normal 1,1 - 1,3 mmol/L)). Jumlah sel darah putih dan kadar hemoglobin masing-masing adalah 19.700/mm3 dan 9,8 g/dl. Ada peningkatan kadar ureum dan kreatinin serum $(67 \mathrm{mg} / \mathrm{dL}$ dan 1,1 $\mathrm{mg} / \mathrm{dL}$ ). CT scan kepala menunjukkan adanya kalsifikasi intrakranial bilateral di ganglia basal, periventrikel, subkortikal, dan serebelum seperti yang terlihat pada Gambar 1.

Penyelidikan lebih lanjut menunjukkan rendahnya kadar PTH 1,55 pg/ml (kadar normal 15 $65 \mathrm{pg} / \mathrm{ml}$ ), magnesium 0,8 mg/dl (kadar normal 1,9 $2,5 \mathrm{mg} / \mathrm{dl}$ ) dan serum albumin 2,4 mg/dl (kadar normal $3,8-5 \mathrm{mg} / \mathrm{dl})$.

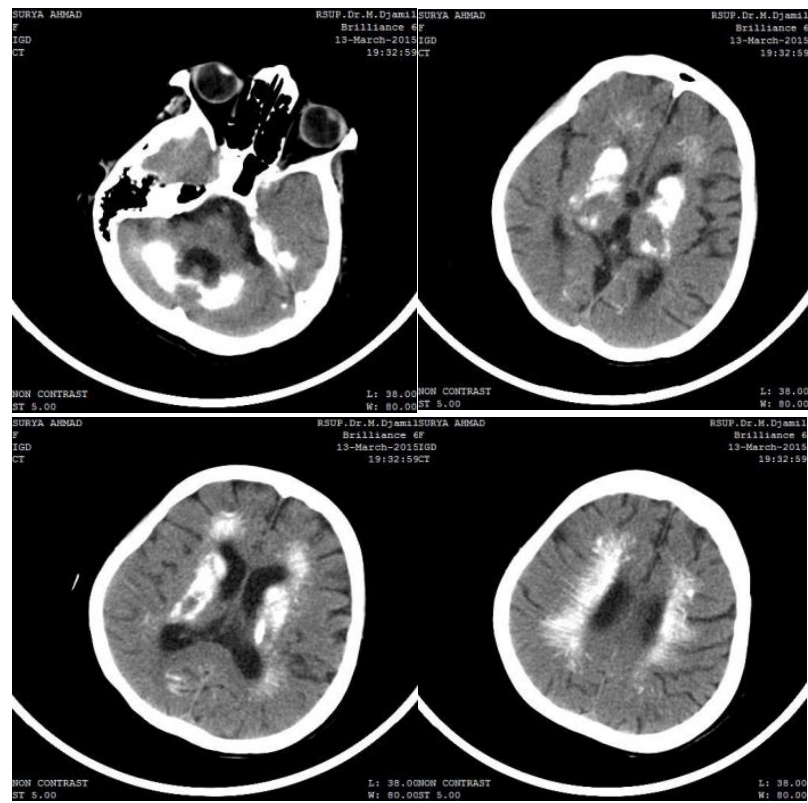

Gambar 1. Brain CT scan tanpa kontras potongan axial, menunjukkan kalsifikasi bilateral ekstensif pada cerebellum, basal ganglia, periventricular subkortikal, dan korona radiata .

Berdasarkan temuan klinis, pemeriksaan fisik, dan pemeriksaan penunjang maka pasien didiagnosis sebagai sindrom Fahr karena hipoparatiroid pascatiroidektomi. Selama rawat inap, kejang terkontrol dengan fenitoin $3 \times 100 \mathrm{mg}$ (IV) dan pasien mendapatkan terapi kalsium glukonas $2 \times 1 \mathrm{gr}$ (IV), 
dan suplementasi calcitriol 0,25 mcg. Pasien menunjukkan perbaikan klinis tetapi masih menunjukkan kekakuan secara global. Selama rawatan, pasien juga mendapatkan koreksi untuk hipomagnesemia dengan drip magnesium sulfat dan koreksi hipoalbuminemia intravena dengan Albumin $20 \%$, dimana kadar magnesium dan albumin dapat mempengaruhi perbaikan kadar kalsium.

Perbaikan klinis semakin baik seiring kadar kalsium mencapai normal, ekstremitas bergerak aktif tetapi kekakuan global masih ditemukan. Pasien lambat dalam berbicara tetapi berorientasi baik pada waktu dan tempat. Pasien dipulangkan dengan kondisi stabil dengan kadar kalsium 7,9 mg/dl, magnesium 2,9 $\mathrm{mg} / \mathrm{dl}$, Albumin $3,3 \mathrm{mg} / \mathrm{dl}$ dan melanjutkan suplementasi kalsium per oral dan calcitriol. Obat kejang dilanjutkan dengan fenitoin $3 \times 100 \mathrm{mg}$ dan asam folat $2 \times 5 \mathrm{mg}$.

\section{PEMBAHASAN}

Kejang memiliki insiden yang tinggi pada pasien dengan usia di atas 60 tahun. Prevalensi epilepsi berkisar $1,5 \%$ untuk orang berusia di atas 60 , dimana hal ini dua kali lebih tinggi dari prevalensi pada dewasa muda. Gangguan neurologis terkait usia seperti gangguan serebrovaskular dan neurodegeneratif merupakan faktor etiologi paling umum untuk epilepsi pada lansia. ${ }^{1}$

Sindrom Fahr sebagian besar terkait dengan gangguan metabolisme kalsium dan fosfat yang terutama berkaitan dengan hipoparatiroidisme (HPT), tetapi juga dapat dikaitkan dengan etiologi lain yang berbeda, termasuk penyakit infeksi, metabolik, dan genetik. Insiden hipoparatiroidisme setelah tiroidektomi total dilaporkan antara $0,3 \%$ dan $6,3 \%$ untuk hipoparatiroidisme permanen dan antara $5 \%$ dan 22\% untuk hipoparatiroidisme transien. ${ }^{2}$ Dalam kasus ini, pasien menderita hipoparatiroidisme (HPT) akibat etiologi iatrogenik (tiroidektomi).

Mekanisme patogenik kalsifikasi basal ganglia (BGC) tidak diketahui, meskipun diyakini karena kontrol kalsium dan fosfor yang buruk pada HPT, terkait dengan hipokalsemia, dan rasio kalsium/ fosfor yang rendah. Peran aktif hormon paratiroid (PTH) dalam fisiologi ganglia basalis juga terlibat. Pada studi histopatologi, sindrom Fahr menunjukkan adanya mineralisasi pada pembuluh darah kecil intraserebral dan ruang perivaskular terutama ganglia basal, struktur cerebellar dan substansia alba, yang sebagian besar terdiri dari hidroksiapatit yang mirip dengan yang ditemukan di tulang, dan elemen lainnya (seperti seng, besi, dan magnesium) yang terperangkap dalam stroma kaya protein tanpa kolagen atau mukopolisakarida. ${ }^{2}$

Lowenthal menetapkan kriteria untuk definisi sindrom Fahr ini (termasuk Penyakit Fahr). Kalsifikasi harus (i) memiliki karakteristik distribusi, melibatkan setidaknya globus pallidus, dengan atau tanpa kalsifikasi serebelum; (ii) terbukti pada CT, dan (iii) cukup untuk dideteksi pada pemeriksaan patologis makroskopik. ${ }^{4}$

Berbagai tanda dan gejala neurologis dikaitkan dengan sindrom Fahr. Pada orang dewasa kehilangan kesadaran dan kejang merupakan salah satu gejala dengan gambaran hipokalsemia terkait hipoparatiroid. Selain itu, ditemukan adanya tetani, yang kadang sulit dibedakan dari epilepsi mioklonus. Tanda-tanda klinis khas iritasi neuromuskular yang terkait dengan tetani laten termasuk hipereflek dan tanda-tanda Chvostek dan Trousseau. Juga, hipertonisitas, gangguan cara berjalan, gangguan bicara, demensia, parkinsonisme, chorea, tremor, dystonia, dan mioklonus dapat ditemukan sebagai manifestasi klinis. Dalam survei pasien dengan kalsifikasi intrakranial, ada laporan bahwa gejala ekstrapiramidal juga ditemukan. 5,6,7

Manifestasi klinis dapat berkorelasi dengan lokasi kalsifikasi. Dalam beberapa literatur, lesi terbanyak dilaporkan terletak di globus pallidus $(88,9 \%)$, putamen $(16,7 \%)$, nukleus caudate $(11 \%)$, thalamus $(5,6 \%)$ dan nukleus dentate serebelum $(5,6)$. \%) dari 18 pasien. ${ }^{5,6}$

Gejala pada sindrom Fahr dapa terdiri dari kejang, gangguan fungsi motorik, spastisitas, dan atetosis. Kalsifikasi kortikal diduga dapat menjadi penyebab epilepsi struktural pada pasien dengan kalsifikasi intrakranial, namun obat anti kejang tidak secara signifikan mengatasi kejang. Hal ini dikaitkan dengan gangguan paratiroid terutama menyebabkan gangguan metabolisme kalsium dan fosfor, dan kalsifikasi intrakranial yang terjadi terkait dengan 
hipokalsemia. Pengobatan pada kejang difokuskan pada suplementasi kalsium dan bukan saja terapi obat anti kejang. ${ }^{8,9}$

Gangguan gerakan dalam sindrom Fahr muncul sebagai spektrum gejala termasuk kelelahan umum, gaya berjalan yang tidak stabil, bicara lambat, disartria, dan gerakan tak terkendali. Gejala neuropsikiatrik berkisar dari gangguan ringan pada konsentrasi dan memori hingga perubahan kepribadian atau perilaku yang mengarah pada psikosis, depresi dan demensia. 5,7

Ditemukan kalsifikasi pada ganglia basal, terutama dengan manifestasi klinis yang jelas, pemeriksaan laboratorium harus dilakukan untuk menilai terjadinya HPT. Temuan khas pada HPT yang tidak diobati adalah kadar PTH sirkulasi yang rendah, hipokalsemia, hiperfosfatemia, rendahnya kadar 1, 25dihidroksivitamin $\mathrm{D}$, dan ekskresi kalsium urin yang relatif tinggi. Evaluasi laboratorium juga harus mencakup serum kreatinin, dan kadar magnesium. Temuan hipokalsemia yang terkait dengan kadar PTH yang tidak terdeteksi cukup untuk mengkonfirmasi diagnosis, karena ia mengesampingkan semua penyebab lain dari hipokalsemia, yang akan mengarah pada peningkatan aktivitas kelenjar paratiroid.2,10

Penyebab paling umum dari HPT adalah kerusakan tidak disengaja atau hilangnya kelenjar paratiroid saat tiroidektomi. Hipoparatiroidisme pasca operasi adalah komplikasi paling umum dari ekstirpasi komplit kelenjar tiroid atau near-complete, dengan destruksi jaringan vaskular paratiroid. Setelah tiroidektomi total, HPT sementara dapat ditemukan pada $10 \%$ pasien. Sebagian besar pasien ini dapat mengalami pemulihan fungsi paratiroid dalam beberapa bulan, namun sekitar $4,4 \%$ berkembang menjadi HPT permanen. Pada HPT pasca operasi, BGC akan berkembang pada pasien yang tidak diobati dalam median waktu 17 tahun. 2,11

Pengobatan sindrom Fahr diarahkan pada penyebab yang dapat diidentifikasi. Terutama pada kasus HPT, perawatan dini dapat mencegah kalsifikasi dan gangguan neurologis lebih lanjut. Pada pasien bergejala, kejang kadang menunjukkan respon yang buruk terhadap antikonvulsan, dan terjadi resolusi ketika kadar kalsium normal tercapai. Parkinsonisme yang muncul juga ditandai oleh resistensi terhadap pengobatan standar, dan pada kasus-kasus awal dapat membaik setelah terapi kalsium. Kejang dan gangguan gerakan pada sindrom Fahr yang terkait dengan gangguan paratiroid dapat diatasi dengan koreksi kadar fosfat dan kalsium. Gejala psikiatri biasanya membaik dengan normalisasi kalsium, meskipun demensia memiliki respon terburuk. $^{2,5}$

Prognosis bervariasi, tidak dapat diprediksi dan tidak berhubungan dengan tingkat kalsifikasi. Perawatan standar HPT melibatkan suplementasi kalsium dan vitamin D atau 1, 25-dihydroxyvitamin D (calcitriol). Tujuan pengobatan termasuk mengontrol gejala, dan menjaga kalsium serum yang rendah mencapai kadar normal. Hipoparatiroid merupakan salah satu dari beberapa penyakit endokrin yang tidak secara rutin diobati dengan penggantian hormon yang hilang, meskipun PTH sintetis subkutan dapat digunakan dalam HPT refrakter. 2

Meskipun merupakan kasus yang jarang, kemungkinan sindrom Fahr harus dipertimbangkan pada pasien dengan gangguan neuropsikiatrik dan kejang. Ketika kalsifikasi basal ganglia ditemukan, maka HPT harus diselidiki, terutama pada pasien yang telah menjalani tiroidektomi.

\section{SIMPULAN}

Kalsifikasi ganglia basal patologis meskipun dapat disebabkan oleh berbagai sebab, namun gangguan metabolik terutama gangguan hormon paratiroid yang berkaitan dengan Sindrom Fahr merupakan penyebab tersering. Kejang disertai manifestasi klinis neuropsikiatri yang bervariasi disertai dengan adanya kalsifikasi bilateral simetris pada gambaran imaging perlu diinvestigasi sebagai kemungkinan gangguan paratiroid terutama pada pasien yang memiliki riwayat operasi tiroidektomi.

\section{DAFTAR PUSTAKA}

1. Toydemir HE, Yalcin AD. Epilepsy in the ederly. Journal of Neurological Disorder. 2014; 2(3): 10681070. 
2. Soares FB, Amorim FF, Santana AR, Moura WB Margalho SB, Amorimc AP, et al. Fahr's Syndrome due to hypoparathyroidism following thyroidectomy. Case Report J Med Cases. 2013;4(6):380-4.

3. Gupta B, Verma JK, Dhanasekaran S. Fahr's Disease: Case Report. Delhi Psychiatry Journal 2013;16(2): 449-50.

4. Sava A, Dumitrescu G, Haba D, Hodorog D, Mihailov C, Sapte E. The Fahr syndrome and the chronic lymphocytic thyroiditis. Rom J Morphol Embryol. 2013; 54(1):195 - 200.

5. Saleem S, Aslam HM, Anwar M, Anwar S, Saleem M, Saleem A, et al. Fahr's syndrome: literature review of current evidence. Orphanet Journal of Rare Diseases. 2013;(8):156-8.

6. Rahman A, Begum R, Hossain M, Ali M, Rahman M. Fahr's Disease: A Rare Neurodegenerative Disorder in Children. J Dhaka Med Coll. 2011;20 (1):86-8.

7. Basak RC. A case report of basal ganglia calcification - a rare finding of hypoparathyroidism. J Oman Medical. 2009; 24(3):220-2.

8. Liu M, Li J, Shi X, Hu L, Zou L. Epileptic seizure as the first symptom of hypoparathyroidism in children does not require antiepileptic drugs. J Child Nerv System. 2017;(33): 297-305.

9. Shahidi G, Safdarian M. Fahr Disease: Idiopathic Basal Ganglia Calcification. Iranian journal of Neurology. 2017;16 (1):53-4.

10. Rizvi I, Ansari N, Shamim D. Widespread intracranial calcification, seizures and extra pyramidal manifestations in a case of hypo parathyroidism. North American Journal Medical Sciences. 2012;4(8):369 -72.

11. Agarwal R, Lahiri D, Biswas A, Mukhopadhyay J, Maity P, Roy MK. A Rare Cause of seizures, parkinsonian, and cerebellar signs: brain calcinosis secondary to thyroidectomy. North American Journal of Medical Sciences. 2014;6(10):540 - 2. 